\title{
GAMBARAN TINGKAT STRES KELUARGA PENDERITA GANGGUAN JIWA DI WILAYAH KERJA PUSKESMAS KABUPATEN KUTAI BARAT
}

\author{
Santosius ${ }^{1}$, Rusdi ${ }^{2}$, Siti Kholifah ${ }^{3}$ \\ ${ }^{1}$ Program Studi IImu Keperawatan, ITKES Wiyata Husada Samarinda \\ Jl. Kadrie Oneing No.77, Samarinda, Kalimantan Timur. \\ e-mail: santosius001@student.itkeswhs.ac.id \\ ${ }^{2}$ Program Studi Profesi Ners, ITKES Wiyata Husada Samarinda \\ Jl. Kadrie Oneing No.77, Samarinda, Kalimantan Timur. \\ e-mail: rusdi@itkeswhs.ac.id \\ ${ }^{3}$ Program Studi IImu Keperawatan, ITKES Wiyata Husada Samarinda \\ Jl. Kadrie Oneing No.77, Samarinda, Kalimantan Timur. \\ e-mail: sitikholifah@itkeswhs.ac.id
}

\begin{abstract}
ABSTRAK
Latar Belakang Stres adalah perasaan tertekan,cemas, tegang, perasaan tidak enak, tidak nyaman, atau tertekan, baik fisik maupun psikis sebagai respon atau reaksi individu terhadap stresor yang mengancam, mengganggu, membebani, atau membahayakan keselamatan, kepentingan, keinginan, atau kesejahtraan hidupnya. Stres yang terjadi pada keluarga pasien gangguan jiwa di karena keluarga merasa terbebani dan kurangnya rasa penerimaan juga kesadaran terhadap keadaan pasien. Tujuan dari penelitian ini untuk mengetahui gambaran tingkat stress keluarga penderita gangguan jiwa Di Wilayah Kerja Puskesmas Tering Seberang Kutai Barat. Metode Penelitian ini merupakan penelitian kuantitatif dengan pendekatan deskriptif. Sampel dalam penelitian ini adalah keluarga penderita gangguan jiwa Di Wilayah Kerja Puskesmas Tering Seberang Kutai Barat dengan jumlah sampel 42 orang. Teknik sampling yang digunakan adalah total sampling. Hasil penelitian menunjukanbahwa mayoritas responden mengalami stress sedang sebanyak 23 orang $(54,8 \%)$, tingkat stress ringan 9 orang $(21,4 \%)$, stress berat 6 orang $(14,3 \%)$, stress normal sebanyak 4 orang $(9,5 \%)$. Mayoritas berusia dewasa (26-45 tahun) sebanyak 24 responden $(57,1)$, mayoritas berjenis kelamin lakilaki sebanyak 27 responden (64,3\%), mayoritas pendidikan SD sebanyak 19 responden $(45,2)$, mayoritas pekerjaan bekerja 35 responden (83,3\%). Kesimpulan Sebagian besar tingkat stress keluarga penderita gangguan jiwa di Wilayah Kerja Puskesmas Tering Sebrang Kabupaten Kutai Barat mengalami stress sedang
\end{abstract}

Kata Kunci : Tingkat stress keluarga, gangguan jiwa 


\section{PENDAHULUAN}

Stres dalam arti secara umum adalah perasaan tertekan,cemas, tegang, perasaan tidak enak, tidak nyaman, atau tertekan, baik fisik maupun psikis sebagai respon atau reaksi individu terhadap stresor yang mengancam, mengganggu, membebani, atau membahayakan keselamatan, kepentingan, keinginan, atau kesejahtraan hidupnya. (Widjianingsih,Suryawan,\& Maramis, 2018). Stres dapat disebabkan oleh beberapa faktor, diantaranya dapat terjadi karena fakor lingkungan, lingkungan yang kondusif akan membuat suasana mood seseorang menjadi baik, begitupun sebaliknya jika kondisi lingkungan yang gaduh, dan tidak kondusif akan membuat seseorang menjadi stress. dikutip (Mahera \& Aiyub, 2017).

Stres merupakan efek paling umum yang sering dirasakan oleh keluarga dari pasien yang menderita penyakit tertentu yang membutuhkan waktu yang lama untuk penyembuhannya. Keadaan tersebut dapat berpengaruh terhadap kualitas hidup keluarga dan pasien itu sendiri kedepannya. (Zhang, Xu, Wang, \& Wang, 2016). Mubin, M. (2013) menyatakan Stres merupakan perasaan yang paling umum dialami oleh pasien yang dirawat di rumah sakit maupun keluarganya, apalagi sakitnya karena salah satu anggota keluarganya menderita gangguan jiwa. Stres keluarga yang muncul bisa berupa rasa malu, isolasi sosial, dan juga rasa kebingungan dalam pemenuhan kebutuhan treatment anggota keluarga yang sakit yang harus dilakukan secara terus menerus. (Mubin, M. 2013).

Menurut definisi Organisasi Kesehatan Dunia World Health Organisasi (WHO), "Gangguan jiwa adalah keadaan kesejahteraan di mana seorang individu dapat mewujudkan kemampuan nya sendiri, berinteraksi secara positif dengan orang lain, mengatasi stres kehidupan dan belajar, bekerja secara produktif dan yang bermanfaat, dan berkontribusi terhadap keluarganya dan masyarakat. "Singkatnya WHO menegaskan karena kehidupan yang penuh stress dan tekenan, penggunaan narkoba dan alasan lainnya, sehingga membuat gangguan jiwa terus meningkat di seluruh dunia. (Haileamlak, 2017).

Kejadian gangguan jiwa diseluruh dunia sudah menjadi masalah serius dan angka penderita gangguan jiwa secara global, diperkirakan bahwa 450 juta orang yang terkena gangguan jiwa. Ini termasuk 121 juta orang dengan depresi, 24 juta dengan skizofrenia. Penderita gangguan jiwa menyumbang sekitar $12,3 \%$ dari beban global. (Iseselo, Kajula, \& YahyaMalima, 2016).

Hampir tiga perempat beban global penyakit gangguan jiwa didapati di Negara berkembang seperti Indonesia. Angka tersebut tergolong sedang dibandingkan dengan negara lainnya. (arianti, novera, \& yani rosa, 2017). Gangguan jiwa berat terbanyak di Yogyakarta sebesar 2,7\%, Aceh sebesar 2,7\%, Sulawesi Selatan sebesar 2,6\%, Bali sebesar 2,3\%, dan Jawa Tengah sebesar 2,3\% (20). Gangguan jiwa di Jawa Tengah, tahun 2014 sudah terdata 1.889 orang, yang terdiri dari 30 orang gangguan mental, 55 orang gangguan neurotik, 1.375 orang gangguan psikotik dan 429 orang epilepsy. (Susanti \& Putra, 2018).

Keluarga merupakan orang terdekat dari seseorang yang mengalami gangguan kesehatan fisik maupun psikis. Apabila di dalam keluarga terdapat anggota keluarga yang menderita sakit atau mempunyai 
masalah maka akan mempengaruhi anggota keluarga yang lain. Beberapa masalah yang dialami oleh keluarga yang memiliki gangguan jiwa yaitu meningkatnya stress (Wulandari, Herawati, \& Setyowati, 2017). Stress juga sering dialami keluarga karena masalah yang muncul dalam keluarga. Gangguan kesehatan yang dialami salah satu anggota keluarga, misalnya gangguan kesehatan jiwa dapat mengganggu pelaksanaan tugas dan fungsi keluarga dalam penelitian (Mahera \& Aiyub, 2017).

Keluarga pasien orang dengan gangguan jiwa dapat menjadi tertekan dengan keadaan yang dialami oleh pasien. Stigma dari masyarakat yang memandang buruk penyakit gangguan jiwa. Stres yang terjadi pada keluarga pasien berupa perasaan tertekan karena lelah dengan keadaan pasien yang membutuhkan perawatan didalam keluarga, perasaan jenuh, perasaan malu dengan keadaan yang terjadi pada pasien, merasa didiskriminasi di lingkungan masyarakat, dan merasa terisolasi dari lingkungan karena stigma masyarakat tentang penyakit gangguan jiwa yang masih buruk (Utama, Dwidiyanti \& Wijayanti, 2020).

Penelitian sebelumnya menyatakan stres yang terjadi pada keluarga pasien skizofrenia berupa perasaan tertekan karena lelah dengan keadaan pasien yang membutuhkan perawatan didalam keluarga, perasaan jenuh, perasaan malu dengan keadaan yang terjadi pada pasien, merasa didiskriminasi di lingkungan masyarakat, dan merasa terisolasi dari lingkungan karena stigma masyarakat tentang penyakit skizofrenia yang masih buruk. (Mahera \& Aiyub, 2017).

Berdasarkan hasil riset kesehatan di provensi Kalimantan Timur tahun 2018, jumlah penderita ganguan jiwa (psikosis/skizofrenia) adalah sebanyak 17.529 orang. Prevalensi orang dengan gangguan jiwa tertinggi ada di DI Yogyakarta dan Aceh (masing-masing $2.7 \%$ ) dan yang terendah di Kalimantan Barat $(0,7 \%)$, provinsi maluku berada pada angka $1,7 \%$. Prevalensi gangguan jiwa berat nasional sebesar 1,7 per mil. Gangguan jiwa berat adalah gangguan jiwa yang ditandai tertinggi yaitu Sulawesi Tengah (11,6\%), sedangkan yang terendah di Lampung dengan terganggunya kemampuan menilai realitas dan tilikan diri (insight) yang buruk. Gejala yang menyertai gangguan ini berupa halusinasi, waham, gangguan proses pikir, dan kemampuan berpikir, dan tingkah laku aneh seperti katatonik.

Data dari RSJD Atma Husada Mahakam Samarinda, yang telah di dapatkan oleh penelitian secara langsung pada tanggal 8 Januari 2020, di wilayah di RSJ Daerah Atma Husada Mahakam Kota Samarinda, peneliti mendapatkan informasi dari pihak rumah sakit bahwa angka kejadian orang dengan gangguan jiwa pada tahun 2019 terdata 12.747 orang dengan gangguan jiwa.

Studi pendahuluan yang dilakukan pada tanggal 9 Juni 2020 di Puskesmas Tering Seberang Kabupaten Kutai Barat dengan berdasarkan hasil dibagikan kuesioner Stres Scale dengan 5 keluarga dengan anggota keluarga dengan penderita gangguan jiwa. Ditemukan 3 anggota keluarga mengalami stres ringan, 2 anggota keluarga mengalami stres sedang. Mereka mengatakan cemas memikirkan masa depan anggota keluarga mereka yang mengalami sakit gangguan jiwa. Anggota keluarga tersebut tampak sulit berkonsentrasi dan kadang diam saat ditanya mengenai keluarganya yang terkena sakit gangguan jiwa. Dari 5 anggota yang saya observasi mereka mengaku tidak malu dengan kondisi anggota keluarganya, mereka mengaku khawatir, cemas akan kesehatan keluarganya.

Penelitian ini bertujuan Untuk mengetahui gambaran tingkat stress pada keluarga penderita gangguan jiwa di wilayah kerja puskesmas tering seberang.

\section{METODE}

Penelitian ini merupakan penelitian kuantitatif dengan pendekatan deskriptif. Sampel dalam penelitian ini adalah keluarga penderita gangguan jiwa Di Wilayah Kerja Puskesmas Tering Seberang Kutai Barat 
dengan jumlah sampel 42 orang. Teknik sampling yang digunakan adalah total sampling.

\section{HASIL PENELITIAN}

Hasil penelitian yang berjudul Gambaran Tingkat Stres Keluarga Penderita Gangguan Jiwa Di Wilayah Kerja Puskesmas Tering Seberang Kabupaten Kutai Barat. Populasi dalam penelitian ini adalah keluarga penderita gangguan jiwa di wilayah kerja Puskesmas Tering Kabupaten Kutai Barat dengan jumlah responden 53 yang di ketahui, dan jumlah responden sebanyak 42 responden keluarga penderita gangguan jiwa di wilayah kerja Puskesmas Tering Kabupaten Kutai Barat.

Tabel 4.1 Distribusi Data Demografi Berdasarkan Jenis Kelamin, Usia, Pendidikan, dan Pekerjaan tingkat stress keluaraga Penderita Gangguan Jiwa Di Wilayah Kerja

Puskesmas Tering Seberang, Kecamatan Tering $(n=42)$

\begin{tabular}{lcc}
\hline \multicolumn{1}{c}{ Katagori } & Jumlah & $\begin{array}{c}\text { Peresentase } \\
\%\end{array}$ \\
\hline $\begin{array}{l}\text { Jenis kelamin } \\
\text { Laki-laki }\end{array}$ & 27 & 64.3 \\
Perempuan & 15 & 35.7 \\
\hline Total & 42 & 100 \\
\hline Usia & & \\
Remaja & 5 & 11.9 \\
Dewasa & 24 & 57.1 \\
Lansia & 13 & 31 \\
\hline & 42 & 100 \\
\hline Pendidikan & & \\
SD & 19 & 45.2 \\
SMP & 15 & 35.7 \\
SMA & 7 & 16.7 \\
PT & 1 & 2.4 \\
\hline Total & 42 & 100 \\
\hline Perkerjaan & & \\
Berkeja & 35 & 83.3 \\
Tidak berkerja & 7 & 16.7 \\
\hline Total & 42 & 100 \\
\hline
\end{tabular}

Sumber data primer 2020

Tabel 4.2 Distribusi Frekuensi Tingkat Stres keluarga Penderita Gangguan Jiwa Di Wilayah Kerja Puskesmas Tering Seberang, Kecamatan Tering $(n=42)$

\begin{tabular}{lcc}
\hline \multicolumn{1}{c}{ Tingkat } & Frequency & Persentase \% \\
\hline Stress & & \\
Normal & 4 & 9.5 \\
Ringan & 9 & 21.4 \\
Sedang & 23 & 54.8 \\
Berat & 6 & 14.3 \\
\hline Total & 42 & 100 \\
\hline
\end{tabular}

Sumber data primer 2020

\section{PEMBAHASAN}

\section{Karakteristik Responden}

a. Jenis Kelamin

Hasil penelitian menunjukan bahwa keluarga pasien dengan gangguan jiwa yaitu paling tinggi berjenis kelamin laki- laki 27 $(64,3 \%)$. Hal ini dikarenakan pada waktu peneliti melakukan penelitian secara kebetulan yang berada dirumah adalah keluarga penderita gangguan jiwa yang berjenis kelamin laki-laki. Hasil penelitian menunjukan bahwa keluarga pasien dengan gangguan jiwa yang mengalami stress berat lebih banyak di alami oleh perempuan 4 $(26,7 \%)$ sedangkan jenis kelamin laki-laki yang emngalami stres berat hanya $2(7,4 \%)$.

Penelitian ini menunjukkan bahwa laki-laki tidak mudah mengalami stress dibandingkan dengan perempuan. Hal ini karena laki-laki yang dituntut untuk lebih kuat dari pada wanita, sehingga laki-laki lebih menggunakan akalnya dari pada perasaannya sedangkan wanita lebih menggunakan perasaannya dalam menghadapi suatu masalah. Laki-laki sejak dulu dipaksa oleh keadaan untuk siap menghadapi masalah sehingga untuk meningkatkan keselamatan dirinya pria mempunyai respon fight or flight (suatu proses dimana organisme akan menilai ancaman yang sdang dihadapinya), hal ini berguna untuk menyelamatkan diri pria dalam melawan stress (Sutjiato, dkk, 2015). 
Respon stres dari setiap orang berbeda. Salah satu respon tersebut adalah tergantung pada jenis kelamin. Perempuan berkemungkinan lebih rentan terhadap kondisi stres, kondisi ini dikendalikan oleh hormon oksitosin, esterogen, serta hormon seks sebagai faktor pendukung yang jelas berbeda tingkatannya pada pria dan wanita (Potter dan Perry, 2005).

Menurut penelitian Sunarni, dkk, (2017) adanya pengaruh hormon esterogen dapat membuat perempuan lebih mudah mengalami stress. Laki-laki tidak mudah mengalami stres meskipun banyak memiliki sumber stres (stressor). Dalam hal dapat dipahami bahwa tidak adanya perbedaan tingkat stres antara perempuan dan laki-laki dalam penelitian ini dikarenakan cara penanganan stres yang dilakukan. Perempuan dan laki-laki memiliki kemampuan beradaptasi yang sama dalam menghadapi stressol yang ada (Sunarni, dkk, 2017).

\section{b. Usia}

Hasil penelitian menunjukan bahwa keluarga pasien dengan gangguan jiwa yaitu paling tinggi berusia dewasa 26-45 tahun berjumlah $24 \quad(57,1 \%)$. Hasil penelitian di wilayah kerja puskesmas tering kecamatan tering kabupaten kutai barat usia dewasa di katagorikan menjadi dewasa awal dan dewasa akhir, usia dewasa awal (26-35 tahun) sedangkan usia dewasa akhir (36-45). Usia dewasa awal, usia dewasa akhir dimana merupakan usia produktif bagi seseorang. Pada usia produktif seseorang cenderung untuk bekerja lebih keras, memikirkan masalah keluarga, ekonomi, dan juga memikirkan masalah pribadi yang sedang dihadapinya sehingga kemungkinan untuk mendapatkan stres sangat tinggi..

Helena et al., (2017). yang menyatakan bahwa tahapan umur dewasa berkonstribusi terhadap terjadinya stres terkait dengan tugas perkembangan yang kompleks. Pada tahap masa dewasa ini, individu mempunyai tanggung jawab kemandirian yang tinggi terkait dengan sosial ekonomi, sumber dukungan, dan kemampuan mengatasi masalah dalam menghadapi stres kehidupan dibanding dengan tahap kehidupan yang lain.

\section{c. Pendidikan}

Hasil penelitian menunjukan bahwa keluarga pasien dengan gangguan jiwa yaitu paling tinggi berpendidikan tamat SD, (45.2\%). Hasil penelitian ini sejalan dengan pendapat Helena et al. (2017) yang menyatakan bahwa pengetahuan berhubungan dengan segala sesuatu yang diketahui yang diperoleh melalui proses pembelajaran, budaya, pendidikan, dan pengalaman hidup lainnya. Asumsi peneliti berdasarkan hasil penelitian dan teori, Semakin tingginya pendidikan anggota keluarga semakin banyak pengetahuan keluarga penderita gangguan jiwa, jika keluarga memliki pengetahuan tentang gangguan jiwa, klien gangguan jiwa akan mendapatkan perawatan yang maksimal sehingga klien gangguan jiwa mendapatkan pelayanan yang cepat dan tepat.

\section{d. Perkerjaan}

Hasil penelitian menunjukan bahwa jenis perkerjaan keluarga pasien dengan gangguan jiwa yang paling tinggi adalah bekerja, sebesar 83,3\%. Hasil penelitian ini sesuai dengan pendapat Thoits (2010) yang menyatakan bahwa dampak stres pada kesehatan dan kesejahteraan dapat dicegah oleh individu dengan mencoba mengatasi kesulitan, menggunakan koping yang tepat dan merencanakan kegiatan yang bermanfaat yaitu dengan bekerja. Berdasarkan hasil penelitian dan teori, peneliti berasumsi bahwa mayoritas dari 
responden mencoba mengatasi tingkat stres salah satunya dengan bekerja atau malah sebaliknya dengan adanya perkerjaan dapat membebani keluarga yang harus dapat memenuhi biaya pengobatan penderita gangguan jiwa dan harus dapat membagi waktu antara berkerja atau mengurus keluarga dengan gangguan jiwa sehingga perkerjaan dapat mempengaruhi keluarga untuk terjadinya stress.

\section{Tingkat Stress.}

Hasil sebaran data pada penelitian tingkat stress keluarga penderita gangguan jiwa di wilayah kerja puskesmas tering kecamatan tering. Data penelitian jumlah responden 42 orang di dapatkan hasil ukur tingkat stress normal sebanyak 4 orang dengan prsentase $(9,5 \%)$, hasil ukur tingkat stress ringan 9 orang dengan prsentase $(21,4 \%)$, hasil ukur tingkat stress sedang 23 orang dengan presentase $(54,8 \%)$ dan hasil ukur tingkat stress berat 6 orang dengan prsentase $(14,3 \%)$.

Hasil dari penelitian menunjukan bahwa keluarga pasien dengan gangguan jiwa paling tinggi mengalami stress sedang dengan presentase $(54,8 \%)$. Hasil dari analisa jawaban responden pada kuesioner penelitian keluarga yang mengalami stress sedang didapatkan keluarga dapat dikatan baik atau mampu yaitu keluarga mampu atau dapat merasakan perasaan positif, keluarga mampu atau dapat untuk tenang setelah sesuatu membuat kesal, keluarga mampu atau dapat bereaksi dengan tenang terhadap situasi yang membuat keluarga stres, keluarga mampu atau dapat bersantai dan keluarga merasa tidak putus asa maupun tidak sedih dengan keadaan keluaraga yang mengalami gangguan jiwa.

Hasil penelitian ini sejalan dengan penelitian Mubin, 2013 menunjukkan bahwa mayoritas mengalami stress sedang sebanyak 52 orang dengan presentase (66,7 \%) (Mubin, 2013). Hasil penelitian ini didukung oleh penelitian dari Accevedo dan Ekkekacis (2006) yang menyatakan bahwa stres dapat disebabkan oleh faktor lingkungan seperti situasi dan kondisi tempat tinggal serta pengalaman masa lalu individu. Dimana bila seseorang mengalami stres dapat menyebabkan perubahan-perubahan dari segi fisiologis yang signifikan diantaranya kesulitan tidur pada malam hari, berkeringat dingin, ketegangan pada otot dan sakit kepala.

Hasil penelitian menunjukan bahwa keluarga pasien dengan gangguan jiwa yang paling tinggi mengalami stress sedang berjenis kelamin laki-laki $(60 \%)$. Sedangkan jenis kelamin perempuan (40\%). Penelitian ini menunjukkan bahwa laki-laki tidak mudah mengalami stress dibandingkan dnegan perempuan. Hal ini karena laki-laki yang dituntut untuk lebih kuat dari pada wanita, sehingga laki-laki lebih menggunakan akalnya dari pada perasaannya sedangkan wanita lebih menggunakan perasaannya dalam menghadapi suatu masalah. Laki-laki sejak dulu dipaksa oleh keadaan untuk siap menghadapi masalah sehingga untuk meningkatkan keselamatan dirinya pria mempunyai respon fight or flight (suatu proses dimana organisme akan menilai ancaman yang sdang dihadapinya), hal ini berguna untuk menyelamatkan diri pria dalam melawan stress (Sutjiato, dkk, 2015).

Hasil penelitian menunjukan bahwa keluarga pasien dengan gangguan jiwa 
yaitu paling tinggi mengalami stress sedang berusia dewasa 26-45 tahun berjumlah $13(56,5 \%)$. Usia dewasa awal, usia dewasa akhir dimana merupakan usia produktif bagi seseorang. Pada usia produktif seseorang cenderung untuk bekerja lebih keras, memikirkan masalah keluarga, ekonomi, dan juga memikirkan masalah pribadi yang sedang dihadapinya sehingga kemungkinan untuk mendapatkan stres sangat tinggi.

Bila dilihat dari tingkatan pendidikan maka tingkat stres sedang paling banyak dialami oleh responden dengan pendidikan SD yaitu $(43,5 \%)$, pendidikan SMP $(30,4 \%)$ dan stress sedang paling rendah pendidikan SMA $(26,1 \%)$. Hasil penelitian ini sejalan dengan pendapat Helena et al. (2017) yang menyatakan bahwa pengetahuan berhubungan dengan segala sesuatu yang diketahui yang diperoleh melalui proses pembelajaran, budaya, pendidikan, dan pengalaman hidup lainnya. Hal ini menunjukkan bahwa tingkat pendidikan dapat mempengaruhi tingkat stres.

Hasil penelitian keluarga mengalami tingkat stress sedang dikarenakan mayoritas sebagian besar tempat penelitian berpencaharian sebagai petani dan responden berpenghasilan kurang sebanyak 30 responden (54,5\%). Hasil penelitian ini sesuai dengan teori fungsi keluarga yang dikemukakan oleh Friedman (2010) yang menyatakan bahwa satu dari lima fungsi pokok keluarga adalah fungsi ekonomi yang merupakan fungsi untuk memenuhi kebutuhan keluarga secara ekonomi seperti makanan, pakaian, perumahan, dll. Pada tahap masa dewasa ini, individu mempunyai tanggung jawab kemandirian yang tinggi terkait dengan sosial ekonomi, sumber dukungan, dan kemampuan mengatasi masalah dalam menghadapi stres kehidupan dibanding dengan tahap kehidupan yang lain.

Hasil dari penelitian penelitian menunjukan bahwa keluarga pasien dengan gangguan jiwa mengalami stress ringan dengan presentase $(21,4 \%)$. Hasil dari penelitian Ekawarna (2018) menyatakan bahwa stress merupakan respon tubuh yang sifatnya non spesifik terhadap setiap tuntutan beban. Cara individu bereaksi terhadap stres bergantung pada cara mereka memandang dan mengevaluasi dampak dari stresor, dukungan saat mengalami stress serta mekanisme koping mereka. Ketika stress mengganggu mekanisme koping seseorang, maka perilaku seseorang akan mengarah ke maladaptif. Meneurut penelitian Taylor (1991) dalam videbeck (2008) menyatakan bahwa stres dapat menghasilkan berbagai respon. Berbagai penelitian telah membuktikan bahwa respon-respon stres tersebut dapat berguna sebagai indikator terjadinya stres pada individu dan mengukur tingkat stres yang dialami individu. Respon stres fisiologis yang terjadi pada individu adalah seperti meningkatnya tekanan darah, mual dan muntah, perubahan nafsu makan, penurunan berat badan, gelisah dan sering terbangun pada malam hari. Videbeck (2008) menyatakan bahwa stres dapat dilihat dengan terganggunya proses kognitif individu, seperti pikiran menjadi kacau, menurunnya daya konsentrasi, pikiran berulang, pikiran yang tidak wajar, kelelahan mental, ansietas dan kehilangan harga diri.

Hasil dari penelitian penelitian menunjukan bahwa keluarga pasien dengan gangguan jiwa mengalami stress berat dengan presentase $(14,3 \%)$. Hasil dari sejalan dengan penelitian Farhan et 
al., (2012) keluarga yang mengalami stres sangat berat dapat disebabkan oleh karena faktor pencetus yang dapat mengaktifkan stres seperti informasi yang didapatkan oleh keluarga tidak adekuat, tanggungan semua biaya perawatan ataupun biaya hidup sehari-hari keluarga saat menunggu pasien, lamanya hari perawatan pasien, dan terganggunya tugas sehari-hari atau pekerjaan keluarga. Hasil penelitian menunjukan bahwa keluarga pasien dengan gangguan jiwa yang mengalami stress berat lebih banyak di alami oleh perempuan $4 \quad(26,7 \%)$ sedangkan jenis kelamin laki-laki yang emngalami stres berat hanya $2(7,4 \%)$. Hasil dari penelitian Sunarni, dkk, (2017) adanya pengaruh hormon esterogen dapat membuat perempuan lebih mudah mengalami stress. Laki-laki tidak mudah mengalami stres meskipun banyak memiliki sumber stres (stressor). Dalam hal dapat dipahami bahwa tidak adanya perbedaan tingkat stres antara perempuan dan laki-laki dalam penelitian ini dikarenakan cara penanganan stres yang dilakukan. Perempuan dan laki-laki memiliki kemampuan beradaptasi yang sama dalam menghadapi stressol yang ada (Sunarni, dkk, 2017).

Hasil penelitian menunjukan bahwa keluarga pasien dengan gangguan jiwa yang tidak bekerja, sebesar $(16,7 \%)$. Maknanya keluarga pasien yang tidak berkerja dapat terjadi stress berat karena keluarga pasien dapat terbebani harus dapat memenuhi biaya pengobatan penderita gangguan jiwa dan harus dapat memenuhi kebutuhan hidup keluarga. Hasil penelitian ini sesuai dengan teori fungsi keluarga yang dikemukakan oleh Friedman (2010) yang menyatakan bahwa satu dari lima fungsi pokok keluarga adalah fungsi ekonomi yang merupakan fungsi untuk memenuhi kebutuhan keluarga secara ekonomi seperti makanan, pakaian, perumahan, dll. Menurut Asumsi peneliti jika pasien tidak memiliki perkerjaan keluarga pasien penderita gangguan jiwa akan beresiko mengalami stress berat dikarenakan penghasilan keluarga yang kurang cukup untuk memenuhi kebutuhan hidup serta kebutuhan pengobatan keluarga pasien penderita gangguan jiwa.

Kesimpulan dari penelitian ini terkait dengan gambaran tingkat stress keluarga penderita gangguan jiwa bahwa stress keluarga penderita gangguan jiwa dapat di katagorikan berdasarkan jenis kemalin, usia, pendidikan dan perkerjaan. Dari hasil penelitian di dapat keluarga penderita gangguan jiwa paling tinggi mengalami stress sedang dan yang paling banyak mengalami stress berat berjenis kelamin perempuan.

\section{KESIMPULAN}

Gambaran tingkat stress keluarga penderita gangguan jiwa di wilayah kerja Puskesmas Tering Seberang Kabupaten Kutai Barat didapatkan frekuensi klasifikasi tertinggi adalah stress sedang dengan jumlah 23 responden $(54,8 \%)$. Karateristik responden mayoritas berusia dewasa (26-45 tahun) sebanyak 24 responden $(57,1)$, mayoritas berjenis kelamin laki-laki sebanyak 27 responden $(64,3 \%)$, mayoritas pendidikan SD sebanyak 19 responden $(45,2)$, mayoritas pekerjaan bekerja 35 responden $(83,3 \%)$.

\section{REFRENSI}

Ekawarna, (2018) Manajemen konflik dan stress; ed. Bunga Sari Fatmawati. Cet.1. Jakarta;Bumi Aksara, 2018. Halaman; 37 \& 41

Haileamlak, A. (2017). Mental Health Disorders: The Deserted Illnesses. Ethiopian Journal of Health Sciences. https://doi.org/10.4314/ejhs.v27i1.1 
Helena, N., Daulima, C., Tinggi, S., Kesehatan, I., Jiwa, D. K., Keperawatan, F. I., ... Barat, J. (2017). Karakteristik keluarga pasien gangguan jiwa yang mengalami stres 1. 4(1), 27-34.

Iseselo, M. K., Kajula, L., \& Yahya, K. I. (2016). The psychosocial problems of families caring for relatives with mental illnesses and their coping strategies: A qualitative urban based study in Dar es Salaam, Tanzania. BMC Psychiatry, 16(1), $1-12$. https://doi.org/10.1186/s12888-0160857-y

Khosandika, F., \& Mubin, M. F. (2017). Family Stress Level That Left Work Outside By Family Members.

Mahera \& Aiyub, (2017). Tingkat Stres Keluarga Dalam Melakukan Rujukan Pasien Dengan Gangguan Jiwa. Aceh: Universitas Syiah Kuala Banda

Mubin, M. (2013). Gambaran Tingkat Stres Pada Keluarga Yang Memiliki Penderita Gangguan Jiwa di Rsud Dr.H.Soewando Kendal. Mubin, M, 299-302.

Mubin, M. F., PH, L., \& Mahmudah, A. R. (2019). Gambaran Tingkat Stres Keluarga Lansia. Jurnal Keperawatan Jiwa, 6(2), 128. https://doi.org/10.26714/jkj.6.2.2018 .128-133

PH, L., Daulima, N. H. C., \& Mustikasari, M. (2018). Relaksasi Otot Progresif Menurunkan Stres Keluarga Yang Merawat Pasien Gangguan Jiwa. Jurnal Keperawatan Indonesia, 21(1), 51-59. https://doi.org/10.7454/jki.v21i1.362

Potter, P. A., (2010). Buku Ajar Fundamental Keperawatan. Jakarta : Penerbit Buku Kedokteran EGC.
Rusdi, R., Mulyono, E., Christina, S., \& Fitri, L. D. N. (2018). Studi Fenomenologi Respon Berduka Akibat Perceraian Orang Tua Pada Remaja Di SMPN 5 Jahab Tenggarong Kutai Kartanegara. AnNadaa: Jurnal Kesehatan Masyarakat, 5(2), 95-100

Sheila L. Videbeck, (2008), Buku Ajar Keperawatan Jiwa, Jakarta: EGC

Thoits, P.A. (2010). Stress and health major finding and policy implications. Journal of health and social behavior 51.1: S541S53. Bloomington: Indiana University

Utama, M., Dwidiyanti, M., Wijayanti, D. Y., Studi, P., Keperawatan, M., Diponegoro, U., Tengah, J. (2020). Penurunan Tingkat Stres Keluarga Pasien Skizofrenia Melalui Reducing Stress Level In Family Members Of Patients With Schizophrenia Through Islamic Spiritual Mindfulness. 8(1), 21-26.

Videebeck, S. L., (2008). Buku Ajar Keperawatan Jiwa. Jakarta : : Penerbit Buku Kedokteran EGC

Wanti, Y., Widianti, E., \& Fltria, N. (2016). Gambaran Strategi Koping Keluarga dalam Merawat Anggota Keluarga yang Menderita Gangguan Jiwa Bera. Jurnal Keperawatan Padjadjaran, v4(n1), 89-97. https://doi.org/10.24198/jkp.v4n1.9

Widjianingsih, E., Suryawan, A., \& Maramis, M. M. (2018). Jurnal Keperawatan Muhammadiyah. 3(2), 22-28.

Wiguna, T., Irawati, R., Noorhana, S. R., Kaligis, F., Nugrahaning, A., \& Belfer, M. L. (2015). Family 
responses to a child with schizophrenia: An Indonesian experience. Asian Journal of Psychiatry. https://doi.org/10.1016/j.ajp.2015.09 .00

Wulandari, Y. Y., Herawati, H., \& Setyowati, A. (2017). Dukungan Sosial Keluarga Dengan Tingkat Stres Anggota Keluarga Yang Merawat Pasien Gangguan Jiwa. Dunia Keperawatan, 4(2), 133. https://doi.org/10.20527/dk.v4i2.251 $\underline{7}$

Zhang, J., Xu, R., Wang, B., \& Wang, J. (2016). Effects of mindfulnessbased

therapy for patients with breast cancer: A systematic review and meta-analysis. Complementary Therapies in Medicine, 26(35), 110.

https://doi.org/10.1016/j.ctim.2016.0 $\underline{2.012}$ 